\title{
Meta-Analysis: The Effect of Malaria Infection on the Incidence of Low Birth Weight
}

\author{
Feri Yuda Anggara'), Setyo Sri Rahardjo²), Bhisma Murti') \\ 1)Masters Program in Public Health, Universitas Sebelas Maret \\ ${ }^{2)}$ Faculty of Medicine, Universitas Sebelas Maret
}

\section{ABSTRACT}

Background: Malaria is a parasitic infectious disease. Malaria contributes to morbidity and mortality in high-risk groups, namely pregnant women and children under five. Malaria infection during pregnancy can adversely affect both the mother and the fetus, including maternal anemia, miscarriage, preterm labor, intrauterine growth retardation, and the delivery of infants with low birth weight (LBW). This study aims to analyze the magnitude of the influence of malaria infection on the incidence of LBW by a meta-analysis study.

Subjects and Method: This was a systematic review and meta-analysis conducted by following the PRISMA flow diagram. The process of searching for articles is carried out through a journal database which includes: PubMed, Springer Link, Google Scholar and Science Direct by selecting articles published in 20002020. Keywords used include: "Malaria infection AND low birth weight", "malaria during pregnant "AND" low birth weight", "malaria during pregnant AND low birth weight AND adjusted ratio". The inclusion criteria were full paper articles with observational study design, articles using English, multivariate analysis used with adjusted odds ratio. Articles that meet the requirements are analyzed using the Revmen5.3 application.

Results: Thirteen articles were reviewed in this study with a cohort and cross-sectional study design. Meta-analysis of 4 cohort studies showed that pregnant women with malaria infection had a 1.31 times increased risk of low birth weight compared with those without malaria infection $(\mathrm{aOR}=1.31 ; 95 \% \mathrm{CI}=0.90$ to $1.90 ; \mathrm{p}=0.15) . \mathrm{A}$ meta-analysis of 9 cross-sectional studies showed that pregnant women with malaria infection had a 2.11 times increased risk of low birth weight compared with those without malaria infection $(\mathrm{aOR}=2.11 ; 95 \% \mathrm{CI}=1.33$ to $3.33 ; \mathrm{p}=0.001)$.

Conclusion: Malaria infection increases the risk of low birth weight.

Keywords: malaria infection, low birth weight

\section{Correspondence:}

Feri Yuda Anggara. Masters Program in Public Health, Universitas Sebelas Maret. Jl. Ir. Sutami 36A, Surakarta 57126, Central Java. Email: feriyudha9o@gmail.com. Mobile: 085220426805.

Cite this as:

Anggara FY, Rahardjo SS, Murti B (2020). Meta-Analysis: The Effect of Malaria Infection on the Incidence of Low Birth Weight. J Matern Child Health. 05(05): 549-562. https://doi.org/10.26911/thejmch.2020.05.05.09.

Journal of Maternal and Child Health is licensed under a Creative Commons Attribution-NonCommercial-ShareAlike 4.o International License.

\section{BACKGROUND}

Malaria is a life-threatening infectious parasitic infection and poses a significant global health threat (Buck and Finnigan, 2019). Malaria contributes to morbidity and mortality, especially in high-risk groups, namely pregnant women and children under five. In 2018, approximately
11 million pregnancies in sub-Saharan Africa with moderate and high transmission countries were affected by malaria infection (WHO, 2019).

Malaria infection during pregnancy can adversely affect the mother and the fetus, including maternal anemia, miscarriage, preterm delivery, intrauterine 
growth retardation, and the delivery of infants with low birth weight are risk factors for causing death (CDC, 2020).

Eleven million pregnant women who were exposed to malaria infection in 2019 gave birth to around 872 thousand children with low birth weight. $16 \%$ of all children with low birth weight are in African countries (WHO, 2019). The number of malaria cases in pregnant women in Indonesia in 2019 was 1,769 . Most cases were reported from Papua province. The highest number of pregnant women screened for malaria was reported from East Nusa Tenggara Province as much as 61,065 , while the total number of pregnant women screened in 2018 was 355,956 (Ministry of Health, 2019).

Malaria infection during pregnancy is a substantial health risk for pregnant women and their fetuses and babies. Pregnant women in high transmission areas are at risk of experiencing decreased immunity due to parasites that will attack the placenta (CDC, 2020). The body's natural immune response to malaria involves both antibody-mediated protection and a cytokine-mediated innate immune response. A placenta infected with malaria is characterized by the presence of red blood cells infected with plasmodium causing an inflammatory response that can disrupt the supply of nutrients from the mother-fetus and cause fetal growth restriction (Quanquin et al., 2020).

Malaria parasite infection in early pregnancy is associated with a delayed effect on fetal growth. Nearly $40 \%$ of these infections occur during the first half of pregnancy, and $18 \%$ occur before the 17th week of pregnancy. These infections can interfere with baseline development of the placenta and therefore reduce final capacity. for nutrient transport across the placenta (Briand et al., 2016).
There is a two-way interaction between nutrition and inflammation. Inflammation negatively impacts nutritional status and poor nutrition negatively impacts immune function. Potentially, decreased immune function due to malnutrition can increase the risk of placental malaria (Lawford et al., 2019). Nutritional deficiencies play a role in increasing the risk of malaria and poor birth outcomes and independently indicate the risk of poor neurodevelopmental outcomes. Pregnancy with malaria affects low birth weight (LBW) (Alvarez et al., 2014).

The risk of birth weight loss occurs with episodes of exposure to malaria either symptomatic or asymptomatic. The reduction in birth weight due to malaria cannot be separated from the condition of anemia in the mother (Rijken et al., 2012).

Meta-analysis is an epidemiological study that combines or combines statistically the results of a number of primary studies that can be combined, testing the same hypothesis in the same way, so as to obtain a quantitative overview (Huque, 1988; Greenhalgh, 1977; Last, 2001; Delgado- Rodriguez, 2001 in Murti 2018). Meta analysis is carried out by summarizing and synthesizing quantitatively the various estimates generated from various similar studies to make the most accurate estimate. This study aims to obtain conclusive conclusions about "The Effect of Malaria Infection on the Incidence of Low Birth Weight".

\section{SUBJECTS AND METHOD}

\section{Study Design}

This was a systematic review and metaanalysis carried out by following the PRISMA flow diagram. The process of searching for articles is carried out by searching through journal databases which include: PubMed, Springer Link, Google 
Scholar and Science Direct. Keywords used include: Malaria infection AND low birth weight", "malaria during pregnant" AND "low birth weight", "malaria during pregnant AND low birth weight AND adjusted ratio".

\section{Inclusion Criteria}

The inclusion criteria for articles that can be reviewed are full paper articles with observational study design, articles in English, the analysis used is multivariate with adjusted odds ratios, the interventions given are those who have a history of malaria infection during pregnancy, the study subjects are pregnant women, the outcome was LBW.

\section{Exclusion Criteria}

Exclusion criteria for articles included primary articles published where metaanalysis was carried out and statistical results reported in the form of a bivariate analysis.

\section{Operational definition of variables}

The article search was carried out by considering the eligibility criteria defined using the PICO model. The population in the study were pregnant women with intervention in the form of malaria infection, the comparison was no malaria infection and the outcomes were LBW.

LBW is a baby with a birth weight of less than $2500 \mathrm{~g}$. The instrument used is the weight scale

Malaria infection is a specific condition in pregnant women and is characterized by the accumulation of red blood cells containing the malaria parasite. The instruments used were the results of microscopic examination, RDT, PCR

\section{Study instrument}

The research stages followed the PRISMA flow diagram and the assessment of the quality of research articles using the Critical Appraisal Skills Program (CASP) for Cohort Study, Critical Appraisal Checklist for Cross-sectional Study (CEBMa, 2014).

\section{Data Analysis}

The data analysis process in this study was carried out using the Review Manager application (RevMen 5.3), to determine the effect size and heterogeneity of the study. The results of meta-analysis data processing are presented in the form of a forest plot and a funnel plot.

\section{RESULTS}

The process of searching for articles is carried out by searching through the database according to PRISMA. The flow diagram can be seen in Figure 1.

Research related to the effect of malaria infection on LBW consisted of 13 articles from the initial search process yielding 1462 articles. The research articles came from 3 continents, namely Asia, Africa and South America. Figure 2 shows the areas where articles were drawn according to the inclusion criteria. Furthermore, the researcher conducted an assessment of the quality of the articles (Tables 1 and 2). Table 3 shows that there are 4 cohort study articles and 9 cross-sectional study articles as evidence of the association of the effect of malaria infection on the incidence of LBW. 
Anggara et al./ The Effect of Malaria Infection on the Incidence of Low Birth Weight

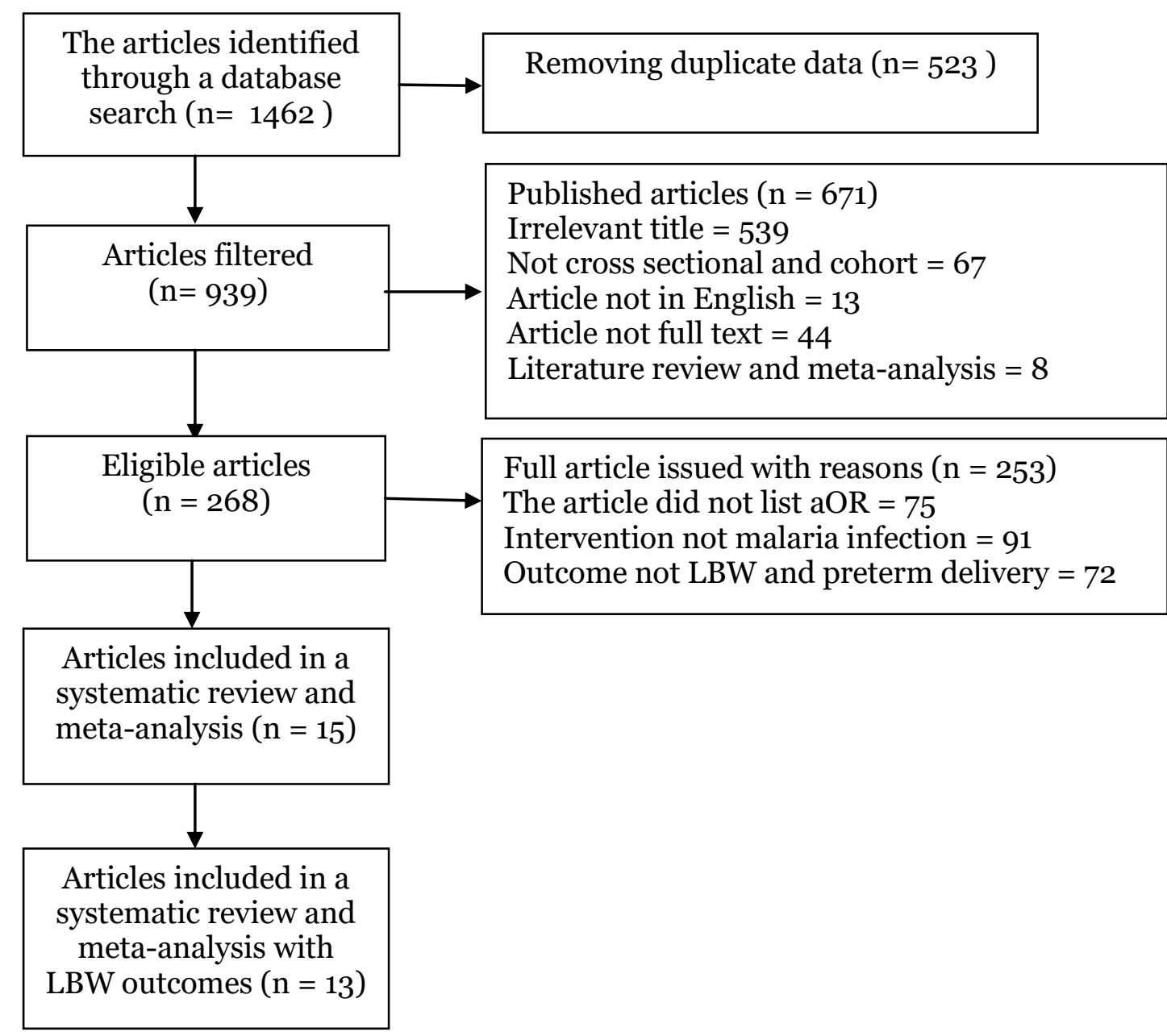

Figure 1. PRISMA flow diagram

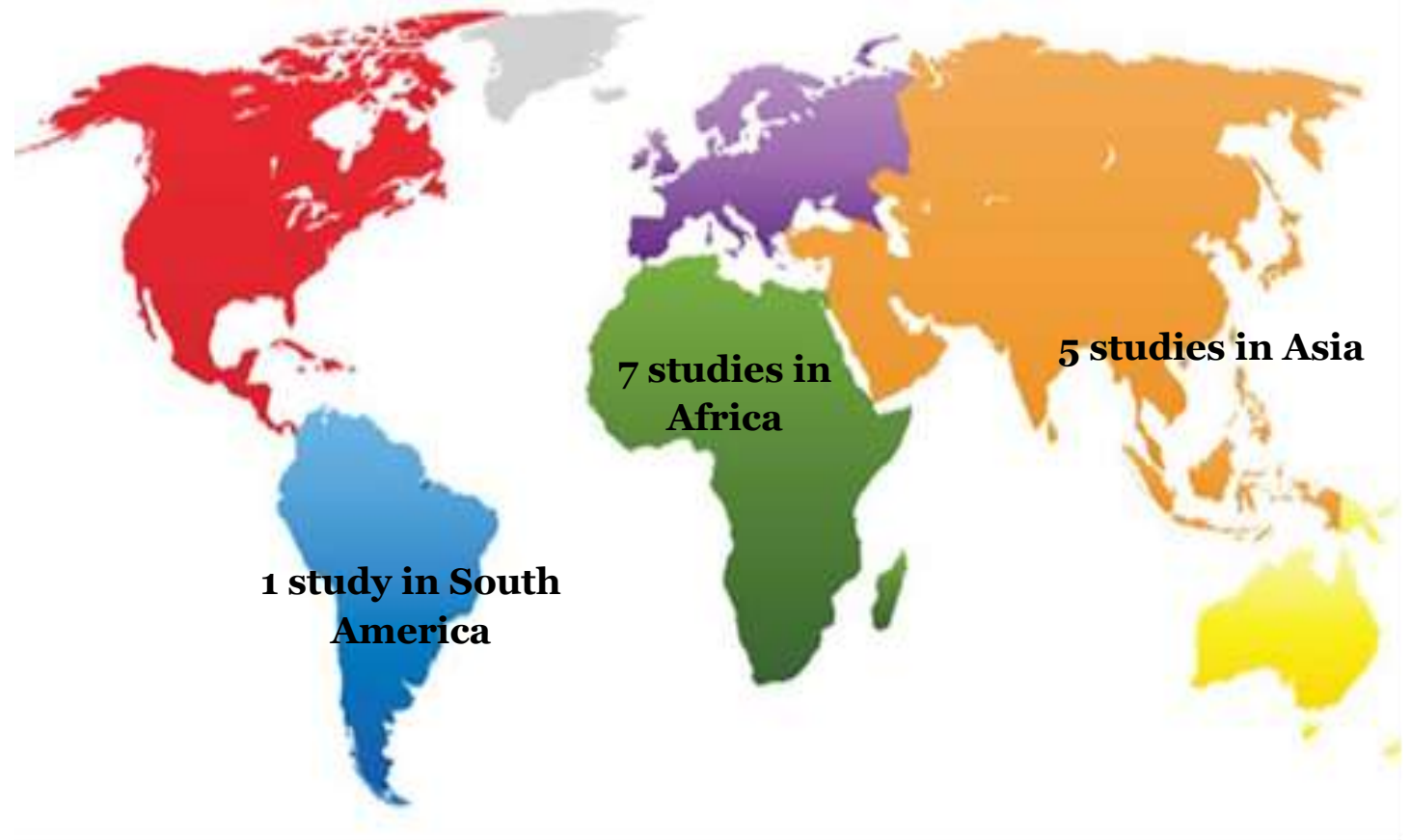

Figure 2. Map of the research area 
Anggara et al./ The Effect of Malaria Infection on the Incidence of Low Birth Weight

Table 1. Assessment of Research Quality using the Critical Appraisal Skills Program for

PUBLI

(Author

\section{Checklist}

Unger et

al. (2019)

\section{Cottrell et}

al. (2015)

Does this research address clearly focused issues?

Was the group included in an acceptable way?

Is exposure measured accurately to minimize bias?

Are the results measured accurately to minimize bias?

Have the authors identified all the important confounding factors?

Was the follow-up to the subject of this study complete?

What are the results of this study?

How precise is the result?

Do you believe in the results?

Can the results be applied to the local population?

Are the results of this study consistent with other available evidence?

What are the implications of this study for practice?

Total

$\begin{array}{cc}1 & 1 \\ 1 & 1 \\ 1 & 1 \\ 1 & 1 \\ 1 & 1 \\ 0 & 0 \\ 1 & 1 \\ 1 & 1 \\ 1 & 1 \\ 0 & 1 \\ 1 & 1 \\ 1 & 1 \\ 10 & 11\end{array}$

Note: $\mathrm{Yes}=1, \mathrm{No}=\mathrm{o}$

Table 2. Assessment of Research Quality using the Critical Appraisal for Cross-sectional

PUBLICATION

(Author andYear)

Checklist

$\begin{array}{cc}\text { Mahande } & \text { Poepspo- } \\ \text { et al. } & \begin{array}{c}\text { prodjo et } \\ \text { (2016) }\end{array} \\ \text { al. (2008) }\end{array}$

Asundep

et al.

(2014)

Albiti

Omer

et al.

et al.

Brutus (

(2016) al. (2008)

(2010) (2010)

al.

(2012) 
Anggara et al./ The Effect of Malaria Infection on the Incidence of Low Birth Weight

\begin{tabular}{|c|c|c|c|c|c|c|}
\hline $\begin{array}{l}\text { Does the sampling method } \\
\text { create bias (selection)? }\end{array}$ & 0 & 0 & 0 & 0 & $\mathrm{O}$ & 0 \\
\hline $\begin{array}{l}\text { Does the research sample } \\
\text { taken represent the designated } \\
\text { population? }\end{array}$ & 1 & 1 & 1 & 1 & 1 & 1 \\
\hline $\begin{array}{l}\text { Was the sample size based on } \\
\text { pre-study considerations? }\end{array}$ & 1 & 1 & 1 & 0 & 1 & 1 \\
\hline $\begin{array}{l}\text { Was a satisfactory response } \\
\text { achieved? }\end{array}$ & 1 & 1 & 1 & 1 & 1 & 1 \\
\hline $\begin{array}{l}\text { Are the research instruments } \\
\text { valid and reliable? }\end{array}$ & 1 & 1 & 1 & 1 & 1 & 1 \\
\hline $\begin{array}{l}\text { Is statistical significance } \\
\text { assessed? }\end{array}$ & 1 & 1 & 1 & 1 & 1 & 1 \\
\hline $\begin{array}{l}\text { Are confidence intervals given } \\
\text { for the main outcome? }\end{array}$ & 1 & 1 & 1 & 1 & 1 & $\mathrm{O}$ \\
\hline $\begin{array}{l}\text { Are there any confounding } \\
\text { factors that have not been } \\
\text { taken into account? }\end{array}$ & 0 & 0 & O & 0 & 0 & O \\
\hline $\begin{array}{l}\text { Are the results applicable to } \\
\text { your research? }\end{array}$ & 1 & 1 & 1 & 1 & 1 & 1 \\
\hline Total & 10 & 10 & 10 & 9 & 10 & 9 \\
\hline
\end{tabular}

Table 3. Description of the primary study meta-analysis of the effect of malaria infection

\begin{tabular}{ccccccc}
\hline $\begin{array}{c}\text { Author } \\
\text { (year) }\end{array}$ & Country & $\begin{array}{c}\text { Study } \\
\text { Design }\end{array}$ & Sample & $\begin{array}{c}\text { P } \\
\text { Population }\end{array}$ & $\begin{array}{c}\text { I } \\
\text { Intervention }\end{array}$ \\
\hline Unger et al. & Papua & Cohort & 2,190 & Pregnant & Peripheral blood microscopic & N
\end{tabular}


Anggara et al./ The Effect of Malaria Infection on the Incidence of Low Birth Weight

\begin{tabular}{|c|c|c|c|c|c|}
\hline $\begin{array}{l}\text { Author } \\
\text { (year) }\end{array}$ & Country & $\begin{array}{l}\text { Study } \\
\text { Design }\end{array}$ & Sample & $\begin{array}{c}\mathbf{P} \\
\text { Population }\end{array}$ & $\begin{array}{c}\text { I } \\
\text { Intervention }\end{array}$ \\
\hline $\begin{array}{l}\text { Stanisic et } \\
\text { al.(2015) }\end{array}$ & $\begin{array}{c}\text { Papua } \\
\text { New } \\
\text { Guninea }\end{array}$ & Cohort & 470 & $\begin{array}{l}\text { Pregnant } \\
\text { women }\end{array}$ & $\begin{array}{l}\text { Primigravida, smoking, educa- } \\
\text { tion, use of mosquito nets, his- } \\
\text { tory of clinical symptoms, } \\
\text { maternal HB, chronic infection } \\
\text { parasitemia }{ }^{*} \text {, genotypes of } \\
\text { SAO, CR1 and } \alpha+\text {-thalassemia, }\end{array}$ \\
\hline $\begin{array}{l}\text { Mahande et } \\
\text { al. (2016) }\end{array}$ & Tanzania & $\begin{array}{c}\text { Cross } \\
\text { sectional }\end{array}$ & 30,797 & $\begin{array}{l}\text { Pregnant } \\
\text { women }\end{array}$ & $\begin{array}{l}\text { Malaria infection *, worm } \\
\text { infection, amoebic infection }\end{array}$ \\
\hline $\begin{array}{l}\text { Poepspo- } \\
\text { prodjo et al } \\
(2008)\end{array}$ & Indonesia & $\begin{array}{c}\text { Cross } \\
\text { sectional }\end{array}$ & 3,046 & $\begin{array}{l}\text { Pregnant } \\
\text { women }\end{array}$ & Malaria parasitemia infection * \\
\hline $\begin{array}{l}\text { Asundep et } \\
\text { al. (2014) }\end{array}$ & Ghana & $\begin{array}{l}\text { Cross } \\
\text { sectional }\end{array}$ & 630 & $\begin{array}{l}\text { Pregnant } \\
\text { women }\end{array}$ & $\begin{array}{l}\text { Malaria infection *, worm } \\
\text { infection }\end{array}$ \\
\hline $\begin{array}{l}\text { Albiti et al. } \\
\text { (2010) }\end{array}$ & Yaman & $\begin{array}{c}\text { Cross } \\
\text { sectional }\end{array}$ & 900 & $\begin{array}{l}\text { Pregnant } \\
\text { women }\end{array}$ & Placental malaria infection * \\
\hline $\begin{array}{l}\text { Ndeserua et } \\
\text { al. (2015) }\end{array}$ & Tanzania & $\begin{array}{c}\text { Cross } \\
\text { sectional }\end{array}$ & 350 & $\begin{array}{l}\text { Pregnant } \\
\text { women }\end{array}$ & Placental malaria infection * \\
\hline $\begin{array}{l}\text { Omer et al. } \\
(2019)\end{array}$ & Sudan & $\begin{array}{c}\text { Cross } \\
\text { sectional }\end{array}$ & 1,149 & $\begin{array}{l}\text { Pregnant } \\
\text { women }\end{array}$ & $\begin{array}{l}\text { living in rural areas, low educa- } \\
\text { tion, irregular ANC visits, use of } \\
\text { mosquito nets, submicroscopic } \\
\text { parasitemia * }\end{array}$ \\
\hline $\begin{array}{l}\text { Brutus et al. } \\
(2013)\end{array}$ & Bolivia & $\begin{array}{c}\text { Cross } \\
\text { sectional }\end{array}$ & 1,507 & $\begin{array}{l}\text { Pregnant } \\
\text { women }\end{array}$ & $\begin{array}{l}\text { Premature babies, babies with } \\
\text { female sex, primiparous, mater- }\end{array}$ \\
\hline
\end{tabular}


Anggara et al./ The Effect of Malaria Infection on the Incidence of Low Birth Weight

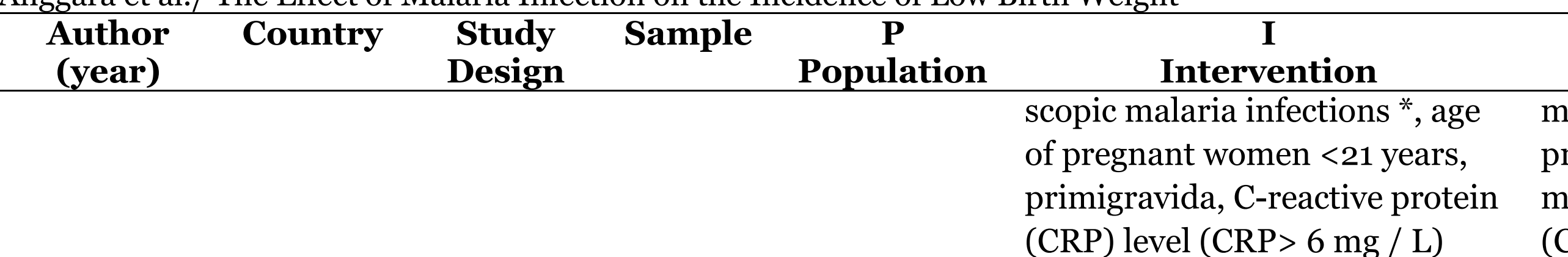

*Variables entered in the meta-analysis 
Anggara et al./ The Effect of Malaria Infection on the Incidence of Low Birth Weight

\section{Forest plot}

Interpretation of the results from the metaanalysis process can be seen through a forest plot. Figure 3 shows that malaria infection increases the incidence of LBW. The meta-analysis results of the cohort study showed that malaria infection could increase the incidence of LBW by 1.31 times compared to LBW incidence that was not affected by malaria infection $(\mathrm{aOR}=1.31$, 95\% CI $=0.90-1.90, \mathrm{p}=0.15)$. The heterogeneity of the research data shows I $2=0 \%$ so that the distribution of the data is declared homogeneous (fixed effect model). The results of the meta-analysis of cross-sectional studies showed that malaria infection increased the incidence of LBW by 2.11 times compared to the incidence of LBW that was not affected by malaria infection $(\mathrm{aOR}=2.11,95 \% \mathrm{CI}=1.33-3.33, \mathrm{p}=0.001)$.
The heterogeneity of the research data shows $I^{2}=77 \%$ so that the distribution of the data is stated to be heterogeneous (random effect model).

\section{Funnel Plot}

A funnel plot is a plot that depicts the estimated effect size of each study on its estimate of accuracy which is usually the standard error. Figure 4 shows that there is a publication bias which is characterized by asymmetry of the right and left plots where 6 plots are on the right, 6 plots are on the left and 1 plot touches the line. The plot on the left of the graph appears to have a standard error between 0 and 0.8 and the plot on the right has a standard error between 0.4 and 1. A bias also occurs from an imbalance between the distances between studies on both the right and left of the funnel plot.

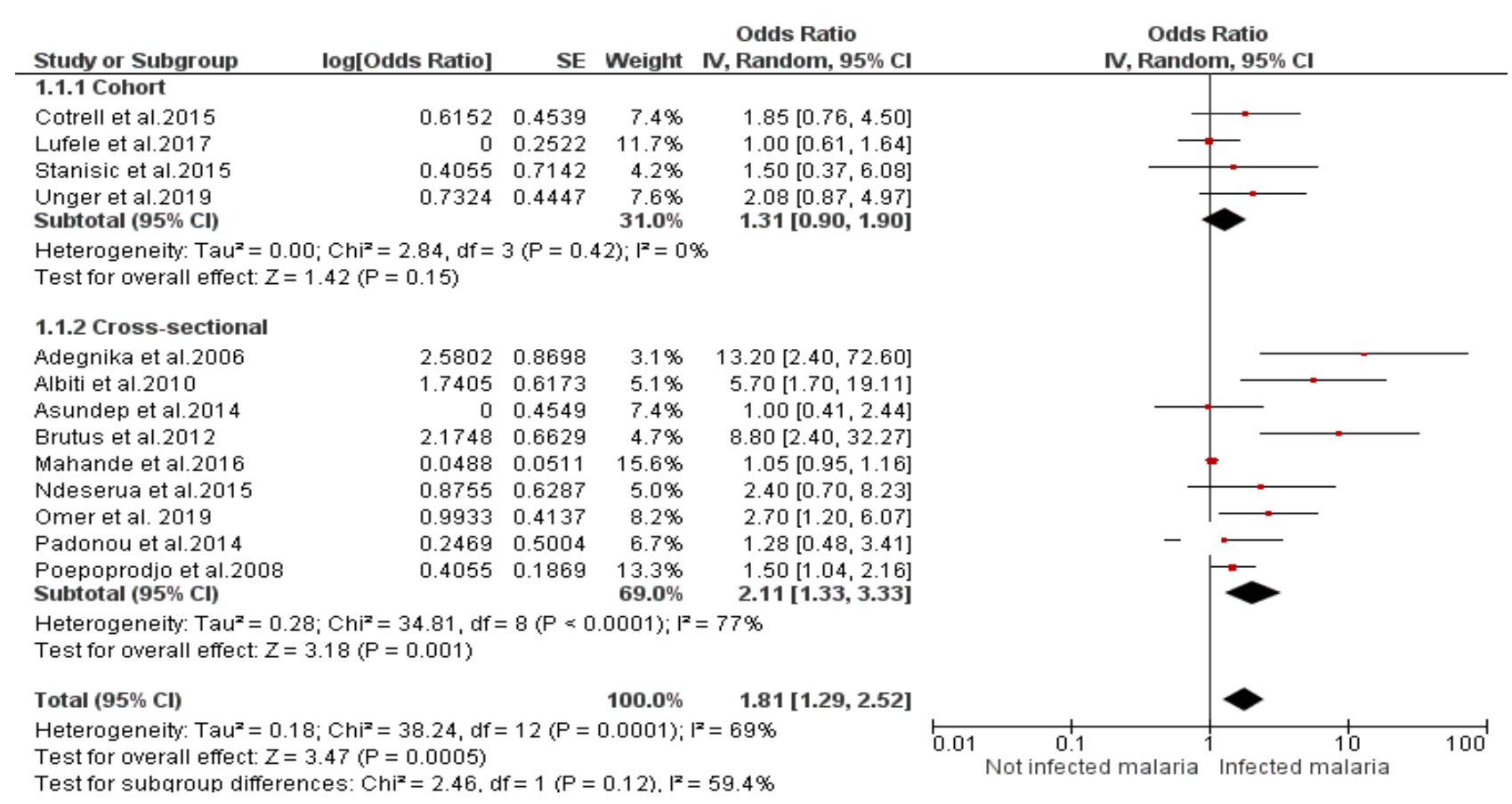

Figure 3. Forest plot of the effect of malaria infection on LBW 


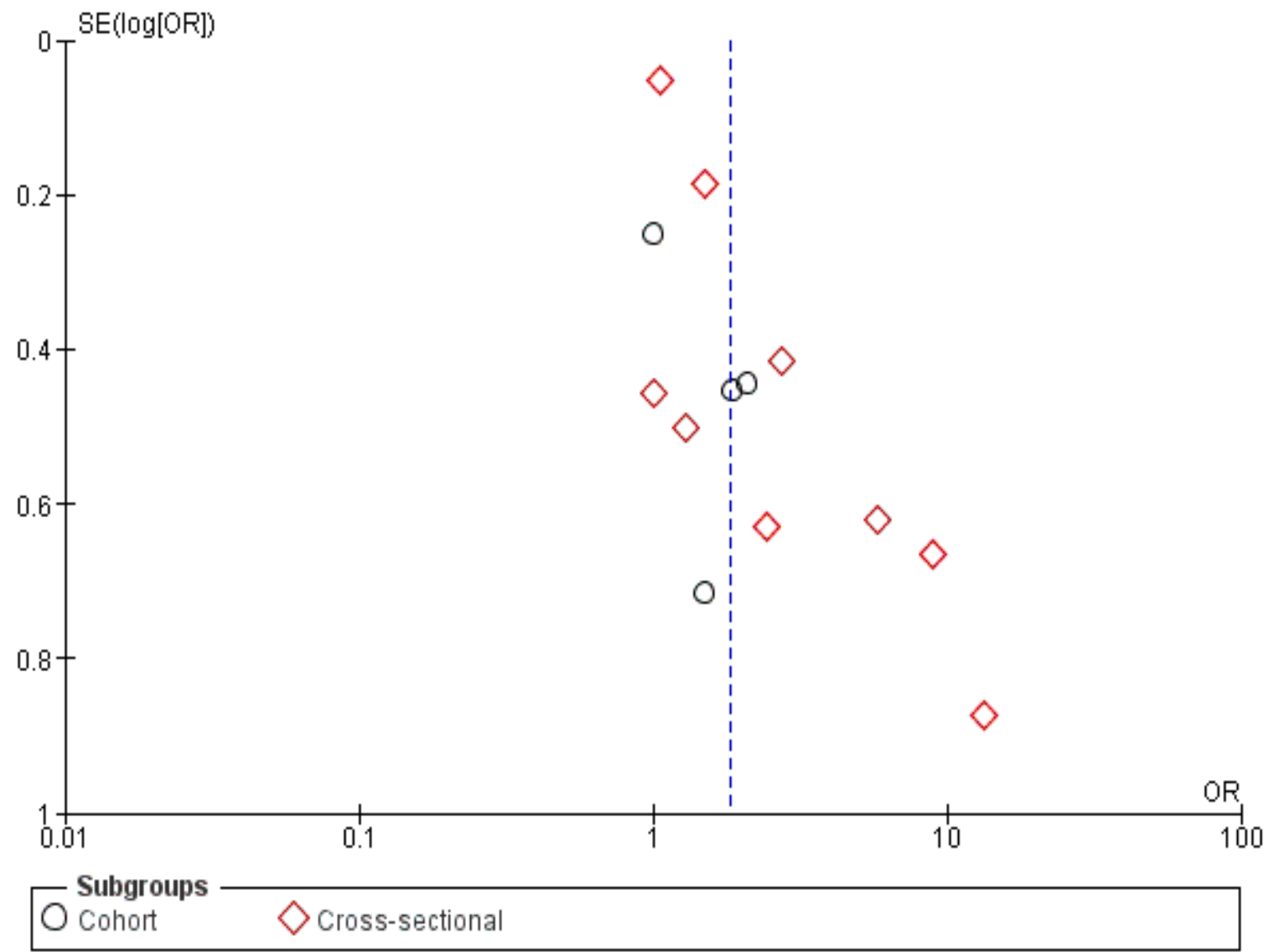

Figure 4.Funnel plot of the effect of malaria infection on LBW

DISCUSSION

This systematic review and meta-analysis research raises the theme of the effect of malaria infection on pregnant women. The independent variable analyzed was malaria infection. The dependent variable in this systematic review and meta-analysis is the incidence of LBW.

The results of the primary study carried out by a systematic study and metaanalysis show an epidemiological study design with a larger population sample, with different demographic characteristics in malaria endemic areas in different countries, thus providing a basis for concluding that malaria infection has a statistical effect on the incidence of birth weight. low.

Malaria is found mainly in climatic factors such as temperature, humidity and rainfall. Malaria is transmitted in tropical and subtropical areas, where the Anopheles mosquito can survive and breed, and the malaria parasite can complete the growth cycle in mosquitoes. Generally, malaria cases occur in warmer areas closer to the equator. The highest transmission rates are found in South Africa's Sahara and in parts of Oceania such as Papua New Guinea (CDC, 2020).

The results of the primary study analysis carried out by systematic review and meta-analysis show that studies that meet the analysis criteria are found in Africa (Benin, Gabon, Tanzania, Ghana, and Sudan), Asia (Indonesia, Papua New Guinea and Yemen), and America. South (Bolivia).

Snow and Guyat (2004) stated that malaria in pregnant women is related to the 
incidence of anemia in mothers, premature delivery, and newborns with low birth weight as a result of infection with the plasmodium falciparum type. During pregnancy, the malaria parasite hides in the placental tissue. Parasite examination in pregnant women is done as a first step to detect and identify cases related to malaria control efforts.

This systematic study study and metaanalysis used research that controlled for confounding factors which could be seen from the study inclusion requirements, namely using multivariate analysis and the statistical result reported was the adjusted odd ratio (aOR). According to Murti (2018), confounding factor is the mixing of estimates of the relationship between exposure and the disease under study, by other factors related, both to disease and exposure. Confounding factors affect the relationship or effect of exposure to the disease occurrence estimated (estimated) by the study is not the same as the relationship or effect that actually occurs in the target population, or the study results are invalid (incorrect).

Estimates of the combined association of the effect of malaria infection with the incidence of LBW and preterm labor were processed using the RevMan 5.3 application with the generic inverse variance method. The results of the systematic review and meta-analysis of this study are presented in the form of a forest plot and a funnel plot.

The forest plot is a diagram that shows visually the amount of variation (heterogeneity), CI, the average between the study results examined in the metaanalysis. A funnel plot is a diagram in metaanalysis used to demonstrate possible publication bias. The funnel plot shows the relationship between the effect size of the study and the sample size of the various studies studied, which can be measured in a number of different ways (Murti, 2018).

\section{The effect of malaria infection on the incidence of low birth weight}

There are 13 observational research articles consisting of 4 cohort studies and 9 crosssectional studies as a source of meta-analysis of the effect of malaria infection on the incidence of LBW. Analyzes were performed with subgroups of each observational study design. The results of the meta-analysis of the cohort study subgroup showed that malaria infection could increase the incidence of LBW by 1.31 times compared to the incidence of LBW that was not affected by malaria infection $(\mathrm{aOR}=1.31 ; 95 \%$ $\mathrm{CI}=0.90-1.90 ; \mathrm{p}=0.15)$. Meanwhile, the meta-analysis of cross-sectional studies showed that malaria infection could increase the incidence of LBW by 2.11 times compared to the incidence of LBW that was not affected by malaria infection (aOR 2.11; 95\% CI 1.33 - 3.33; $\mathrm{p}=0.001$ ).

The results of this study are in line with the study conducted by Rudono et al. (2005) which stated that pregnant women infected with malaria in the first trimester have an increased risk of LBW by 5.9 times $(\mathrm{aOR}=5.9 ; 95 \% \mathrm{CI}=1.02-34.11)$ higher than pregnant women who did not suffer from malaria during pregnancy. Pregnant women infected with malaria increased the incidence of LBW 6.2 times (aOR 6.2; 95\% CI 1.83-32.85) higher than pregnant women who did not suffer from malaria in the second trimester. Pregnant women suffering from malaria due to plasmodium falciparum infection increased the incidence of LBW by 6.7 times higher than pregnant women who did not suffer from malaria (aOR 6.7; 95\% CI 1.45-31.20).

Malaria can affect birth weight through anemia caused by plasmodium infection. Malaria can also reduce birth weight through the effects of placental 
infection. In this regard, parasites either directly cause mechanical impairment of placental circulation through extensive thickening of the trophoblast basement and increased fibrinoid necrosis and cytoplasmic superiority or indirectly interfere with placental function and or cause pathological lesions. from 5 percent to 52 percent, the risk of LBW associated with infection increases two to four times in various studies (Uneke, 2007).

The results of a study conducted by Walther et al, (2010) in West Africa showed that babies born first to third to mothers with a history of malaria infection were significantly lighter, thinner, had lower BMI scores than babies of mothers without a history of malaria infection. Infants exposed to malaria infection were 2.4 times more likely to be thin at three months of age and 3.1 times more likely to be underweight at 12 months of age than babies born to mothers without the infection

The results of research conducted by Omer et al. (2017) stated that placental malaria infection can increase the risk of maternal anemia and significantly affect the incidence of LBW by 25.2 times compared to pregnancies without placental malaria infection in pregnancy outcomes in the country of Sudan (aOR= 25.2; $\mathrm{CI}=95 \%$ 15.1-41.3). This meta-analysis study concluded that malaria infection increases the risk of low birth weight.

\section{AUTHOR CONTRIBUTION}

Feri Yuda Anggara is the principal author who selects topics, explores and collects research data. Setyo Sri Rahardjo and Bhisma Murti played a role in analyzing the data and reviewing research documents

\section{CONFLICT OF INTEREST}

There is no conflict of interest in this study.

\section{FUNDING AND SPONSORSHIP}

This study uses funds from the Education Fund Management Institute (LPDP) of the Ministry of Finance of the Republic of Indonesia.

\section{ACKNOWLEDGEMENT}

We are very grateful to the database providers PubMed, ScienceDirect, Springer Link and Google Scholar.

\section{REFERENCE}

Adegnika AA, Verweij JJ, Agnandji ST, Chai SK, Breitling LP, Ramharter M, Frolich M, Issifou S, Kremsner PG, Yazdanbakhsh M (2006). Microscopic and sub-microscopic Plasmodium falciparum infection, but not inflammation caused by infection, is associated with low birth weight. AmJ Trop Med Hyg. 75(5): 798-803. https://doi.org/10.4269/ajtmh.2006. 75.798.

Albiti AH, Adam I, Ghouth AS (2010). Placental malaria, anaemia and low birthweight in Yemen. Trans $\mathrm{R}$ Soc Trop Med Hyg. 104(1):191-194. https://doi.org/10.1016/j.trstmh.2009.07. 004.

Alvarez MV, Abellana R, Cot M (2014). Pregnancy-associated malaria and malaria in infants: an old problem with present consequences. Malar J. 13(1): 1-10. https://doi.org/10.1186/1475-2875-13-271.

Asundep N N, Jolly PE, Carson AP, Turpin CA, Zhang K, Wilson NO, Stiles JK (2014). Effect of malaria and geohelminth infection on birth outcomes in Kumasi, Ghana.Int J Trop Dis Health. 4(5):582-594. doi: 10.9734/IJTDH/ 2014/7573.

Briand V, Saal J, Ghafari C, Huynh B, Fievet N, Schmiegelow C, Massougbodji A (2016). Fetal growth restriction 
is associated with malaria in pregnancy: a prospective longitudinal study in Benin. J Infect Dis. 214(3): 417-425. https://doi.org/10.1093/infdis/jiw158.

Brutus L, Santalla J, Schneider D, Avila JC, Deloron P (2013). Plasmodium vivax malaria during pregnancy in Bolivia. Emerging Infect. Dis. 19(10):16051611. www.cdc.gov/eid.

Buck E, Finnigan NA (2019). Malaria. Stat Pearls Publishing LLC. NCBI Bookshelf ID: NBK551711PMID: 31869175.

CDC (2020). Malaria. https://www.cdc.gov/malaria/about/distribution.html. Diakses tanggal 25 Oktober 2020

CEBMa (2014). Critical Appraisal. Amsterdam: Center for Evidence Based Management

Cottrell G, Moussiliou A, Luty AJF, Cot M, Fievet N, Massougbodji A, Deloron P, Ndam TN (2015). Submicroscopic plasmodium falciparum infections are associated with maternal anemia, premature births, and low birth weight. Clin Infect Dis. 60(10):14811488. https://doi.org/10.1093/cid/civ122.

Guyat HL, Snow RW (2004). Impact of malaria during pregnancy on low birth weight in Sub- Sahara Africa. Clin Microbiol Rev. 17(4): 760-769. https://doi.org/10.1128/CMR.174.760

Kementerian Kesehatan RI (2019). Situasi terkini perkembangan program pengendalian malaria di Indonesia tahun 2018 (The latest situation in the development of the malaria control program in Indonesia in 2018). Jakarta: Indonesia.

Lawford HLS, Lee ACC, Kumar S, Liley HG, Bora S (2019). Establishing a conceptual framework of the impact of placental malaria on infant neurodevelopment. Int J Infect Dis 84(1):
54-65. https://doi.org/10.1016/j.ijid.2019.04.019.

Lufele E, Umbers A, Ordi J, Kaius MO, Wangnapi R, Unger $\mathrm{H}$, Tarongka $\mathrm{N}$, Siba P, Mueller I, Robinson L, Rogerson $S$ (2017). Risk factors and pregnancy outcomes associated with placental malaria in a prospective cohort of Papua New Guinean women. Malar J. 16(427):1-10. https://doi.org/10.1186/s12936-017-2077-4.

Mahande AM, Mahande MJ (2016). Prevalence of parasitic infections and associations with pregnancy complications and outcomes in northern Tanzania: a registry-based cross-sectional study. BMC Infect Dis. 16(78):1-9. https://doi.org/10.1186/s12879-016-1413-6.

Murti B (2018) Prinsip dan metode riset epidemiologi. $5^{\text {th }}$ edn. Surakarta: Program Studi Ilmu Kesehatan Masyarakat, Program Pascasarjana, Universitas Sebelas Maret.

Ndeserua R, Juma A, Mosha D, Chilongola $J$ (2015). Risk factors for placental malaria and associated adverse pregnancy outcomes in Rufiji, Tanzania: a hospital based cross sectional study. Afr Health Sci. 15(3): 810-818. https://doi.org/10.4314/ahs.v15i3.15.

Omer SA, Noureldein AN, Eisa H, Abdelrahim M, Idress HE, Abdelrazig AM, Adam I (2019). Impact of submicroscopic plasmodium falciparum parasitaemia on maternal anaemia and low birth weight in Blue Nile State, Sudan. J Trop Med (1):316-378, https://doi.org/10.1155/2019/3162378

Omer SA.,Idress HE, Adam I, Abdelrahim M, Noureldein AN, Abdelrazig AM, Elhassan MO, Sulaiman SM (2017). Placental malaria and its effect on pregnancy outcomes in Sudanese women from Blue Nile State. Malar J. 16(347): 1-8. https://doi.org/10.1186- 
Anggara et al./ The Effect of Malaria Infection on the Incidence of Low Birth Weight

/s12936-017-2028-o.

Padonou G, Le Port, A, Cottrell G, Guerra J, Choudat I, Rachas A, Bouscaillou J, Massougbodji A, Garcia A, MartinPrevel Y (2014). Prematurity, intrauterine growth retardation and low birth weight: Risk factors in a malaria-endemic area in Southern Benin. Trans R Soc Trop Med Hyg. 108(2): 77-83. https://doi.org/10.1093/trst$\mathrm{mh} /$ trto99.

Poespoprodjo JR, Fobia W, Kenangalem E, Lampah DA, Warikar N, Seal A, Mcgready R, Sugiarto P, Tjitra E, Anstey NM, Price RN (2008). Adverse pregnancy outcomes in an area where multidrug-resistant Plasmodium vivax and Plasmodium falciparum Infections Are Endemic. Clin Infect Dis. 46 (1):1-8. https://doi.org/10.10$86 / 586743$.

Quanquin NM, Barres LG, Aliyari SR, Day NT, GeramiH, Fisher SJ, Kakuru A, Kamya MR, Havlir DV, Feeney M, Dorsey G, Cheng G, Gaw SL (2020). Gravidity-dependent associations between interferon response and birth weight in placental malaria. Malar J. 19(280):1-8. https://doi.org/10.1186/s12936-020-03351-0.

Rijken MJ, Mcgready R, Boel ME, Poespoprodjo R, Singh N, Syafruddin D, Rogerson S, Nosten F (2012). Malaria in pregnancy in the Asia-Pacific region. Lancet Infect Dis. 12(1):75-88. https://doi.org/10.1016/S1473-3099(11)70315-2.

Rudono, Dasuki D, Mukti AG (2005). Hubungan penyakit malaria pada ibu hamil dengan kejadian berat badan lahir rendah di daerah endemic malaria kabupaten Purworejo (The relationship between malaria in pregnant women and the incidence of low birth weight in malaria endemic areas,
Purworejo district). Sains Kesehatan. 18(2): 221-235.

Stanisic DI, Moore KA, Baiwog F, Ura A, Clapham C, King CL, Siba PM, Beeson JG, Mueller I, Fowkes FJ, Rogerson SJ (2015). Risk factors for malaria and adverse birth outcomes in a prospective cohort of pregnant women resident in a high malaria transmission area of Papua New Guinea. Trans R Soc Trop Med Hyg. 109(5):313324. https://doi.org/10.1093/trstmh/trvo19.

Uneke CJ (2007). Impact of placental Plasmodium falciparum malaria on pregnancy and perinatal outcome in subSaharan Africa. II: Effects of placental malaria on perinatal outcome; malaria and HIV. Yale J Biol Med. 8o(3): 95-103. https://www.ncbi.nlm.nih.gov/pubmed/18160989.

Unger HW, Rosanas UA, Robinson LJ, Ome KM, Jally S, Umbers AJ, Pomat W, Mueller I, Kattenberg E, Rogerson SJ (2019). Microscopic and submicroscopic Plasmodium falciparum infection, maternal anaemia and adverse pregnancy outcomes in Papua New Guinea: A cohort study. Malaria J, 18(1): 2-9. https://doi.org/10.1186/s12936-019-2931-7.

Walther B, Miles DJC, Crozier S, Waight P, Palmero MS, Ojuola O, Touray E, Sande MVD, Whittle H, Jones SR, Flanagan KL (2010). Placental malaria is associated with reduced early life weight development of affected children independent of low birth weight. Malar J. 9(16):1-10. https://doi.org/10.1186/1475-2875-9-16.

World Health Organization (2019). World malaria report 2019. Geneva. https://www.who.int/publicationsdetail/world-malaria-report-2019. 